\title{
Study of endometriosis in women of reproductive age, laparoscopic management and its outcome
}

\author{
Hariharan Valson ${ }^{1}$, Chinmay Kulkarni ${ }^{1}{ }^{*}$, Bhavuray Teli ${ }^{2}$, Nazer T. ${ }^{1}$
}

\begin{abstract}
${ }^{1}$ Department of Obstetrics and Gynaecology, ${ }^{2}$ Department of General and Laparoscopic surgery, DM Wayanad Institute of Medical Sciences, Wayanad, Kerala, India
\end{abstract}

Received: 26 January 2016

Accepted: 02 February 2016

\section{*Correspondence:}

Dr. Chinmay Kulkarni,

E-mail: kulkarnichinnu@gmail.com

Copyright: $\odot$ the author(s), publisher and licensee Medip Academy. This is an open-access article distributed under the terms of the Creative Commons Attribution Non-Commercial License, which permits unrestricted non-commercial use, distribution, and reproduction in any medium, provided the original work is properly cited.

\begin{abstract}
Background: The prevalence of endometriosis is seen to be from $10 \%$ to $20 \%$ in the reproductive age group. The prevalence of endometriosis is $30 \%$ to $70 \%$ among women presenting with infertility. In our study the incidence of endometriosis appears to be on the higher side. The objective is to find out the prevalence of endometriosis in the female population in the reproductive age and to study the outcome after laparoscopic surgery in infertile women with endometriosis

Methods: A total of 200 patients who presented with symptoms of dysmenorrhoea, dyspareunia, chronic pelvic pain with or/without infertility were studied in the women of reproductive age group. The diagnostic/operative laparoscopy was performed in 75 patients. Endometriosis was identified by laparoscopy in 50 cases and confirmed by histopathological examination.

Results: Out of the above 200 patients, $25 \%$ (50 cases) were diagnosed as cases of endometriosis. Out of which, 50\% ( 25 cases) patients had moderate to severe endometriosis. The prevalence of infertility was $22.5 \%$ (45cases out of 200). Endometriosis was the cause of infertility in 33 patients. 25 patients had moderate to severe endometriosis and remaining 8 cases minimal to mild disease. The prevalence of endometriosis was $73.33 \%$ in infertile women. The fertility rate after surgery, during the 2 years follow up is $36.36 \%$ ( 12 cases conceived out of 33 cases).

Conclusions: The prevalence of endometriosis in infertile women is higher and the outcome after laparoscopic surgery is encouraging. The symptoms and clinical signs should raise the suspicion of pelvic endometriosis.
\end{abstract}

Keywords: Infertility, Laparoscopy, Endometriosis, Pelvic pain, Dysmenorrhoea

\section{INTRODUCTION}

Endometriosis is defined as a chronic and recurrent disease characterised by the presence and proliferation of endometrial glands and stroma outside the uterine cavity. It is responsible for varied and disabling symptoms and it also has an adverse impact on fertility. The incidence of endometriosis remains unknown because of the poor correlation between its presence and symptoms. The prevalence of endometriosis in reproductive women is around $10 \%$ to $20 \%$ and endometriosis is the cause of infertility in $30 \%$ to $70 \%$ of patients coming for infertility investigation. ${ }^{1,2}$
The aetiology of endometriosis is complex and multifactorial. ${ }^{3}$ Even though it is benign in nature; the majority of women do not improve if left untreated. The most common symptoms of endometriosis are dysmenorrhoea, dyspareunia, pelvic pain and infertility. ${ }^{4}$ A large prospective study by Adamson et al, 1993 showed that laparoscopic surgery significantly increased the cumulative pregnancy rate which was confirmed by a further meta-analysis in 1994. The surgical modalities include laparoscopy and laparotomy. Medical hormone treatment has been unsuccessful in treating infertile women as it does not improve the fertility rate; but it has a role in providing symptomatic relief and suppressing 
the disease after laparoscopic surgery. ${ }^{5}$ Laparoscopic surgery is widely used as a diagnostic and therapeutic tool as it has quicker recovery time, shorter hospital stay, reduced physical and psychological stress, unlike laparotomy.

This study was done to find out the prevalence of endometriosis in the female population and to know the outcome after laparoscopic surgery.

\section{METHODS}

This study was performed at DM WIMS Medical College, Wayanad, Kerala, between 01 Dec 2012 to 31 Dec 2014. The patients included in the study were in the age group 20 to 45 years with symptoms of dysmenorrhoea, dyspareunia, pelvic pain and infertility. Pelvic examination was done and clinical findings of POD tenderness with nodular surface, restricted mobility of uterus or fixed retroverted uterus with adnexal mass either unilateral or bilateral were noted. These cases were subjected for pelvic ultrasound (USG) to look for altered pelvic anatomy and ovarian endometriomas. Diagnostic standard three-trocar laparoscopy was done under general anaesthesia, with a $10 \mathrm{~mm}$ operating laparoscope inserted through an umbilical port and two $5 \mathrm{~mm}$ sheaths inserted in the lower abdominal quadrants lateral to the inferior epigastric artery.

Disease staging was done using the Revised- American Fertility Society (R-AFS) classification score. Scores 1 to 5 were classified as stage 1 (minimal), scores from 6 to 15 were stage 2 (mild), scores 16 to 40 with mild adhesions were classified as stage 3 (moderate) and scores above 40 classified as stage 4 (severe). Ovarian endometriomas were a marker of severe disease.

In the operative laparoscopy removal of lesions was done by:

1. Bipolar cauterisation and laparoscopic scissors.

2. The endometriomas were removed by cystectomy with maximum conservation of ovarian tissue.

3. Drainage and fulguration in very difficult cases.

4. Adhesiolysis for adhesions was done.

5. Chromopertubation was done to see tubal patency in all cases of infertility (45cases).

All the specimens retrieved were sent for histopathological (HPE) confirmation.

\section{RESULTS}

The prevalence of endometriosis (Table1) in women, who were included in the study, was found to be high (25\%). The incidence of infertility was $22.5 \%$ (45) among the total cases (200) included in the study. In clinical examination, $37.5 \%$ (75 patients) were suspected to have endometriosis and subjected to pelvic ultrasound. USG pelvis revealed altered pelvic anatomy in some cases and ovarian endometriomas in $20 \%$ (16 cases out of 75). Diagnostic/operative laparoscopy was done in 75 cases. Endometriosis was diagnosed in 50 cases, moderate to severe disease was seen in 25 cases and remaining 25 cases had minimal to mild disease. Pelvic endometriosis was the cause of infertility in 33 cases. There is increased prevalence of endometriosis in 20-30 years age group.

Table 1: The prevalence of endometriosis in various age groups.

\begin{tabular}{|lll|}
\hline $\begin{array}{l}\text { Age group } \\
\text { (years) }\end{array}$ & No. of patients & Prevalence (\%) \\
\hline $20-30$ & 25 & $50 \%$ \\
\hline $31-40$ & 21 & $42 \%$ \\
\hline $41-45$ & 04 & $8 \%$ \\
\hline
\end{tabular}

The prevalence of overall infertility (Table 2) was highest in the 20 to 30 years age group $(78.78 \%)$. The prevalence of endometriosis was $73.33 \%$ in women suffering from infertility.

Table 2: Age wise distribution of infertility in endometriosis.

\begin{tabular}{|llll|}
\hline $\begin{array}{l}\text { Age group } \\
\text { (years) }\end{array}$ & $\begin{array}{l}\text { Primary } \\
\text { infertility }\end{array}$ & $\begin{array}{l}\text { Secondary } \\
\text { infertility }\end{array}$ & $\begin{array}{l}\text { Prevalence } \\
(\%)\end{array}$ \\
\hline $20-30$ & 20 & 06 & 78.78 \\
\hline $31-40$ & 02 & 05 & 21.22 \\
\hline $41-45$ & nil & nil & nil \\
\hline
\end{tabular}

The maximum number of patients with endometriosis belongs to stage 3 (Table 3 ). The higher prevalence $(75 \%)$ of infertility was observed in stage 3 and 4 diseases (25 out of 33 cases).

Table 3: Distribution of patients according to (R-AFS) classification and staging.

\begin{tabular}{|llll|}
\hline $\begin{array}{l}\text { Stage of the } \\
\text { disease }\end{array}$ & $\begin{array}{l}\text { No. of } \\
\text { patients }\end{array}$ & $\begin{array}{l}\text { Prevalence of } \\
\text { endometriosis in } \\
\text { various stages } \\
(\%)\end{array}$ & $\begin{array}{l}\text { No. of } \\
\text { patients } \\
\text { with } \\
\text { infertility }\end{array}$ \\
\hline Stage 1 & 12 & $24 \%$ & 3 \\
\hline Stage 2 & 13 & $26 \%$ & 5 \\
\hline Stage 3 & 15 & $30 \%$ & 15 \\
\hline Stage 4 & 10 & $20 \%$ & 10 \\
\hline
\end{tabular}

A total of 16 cases had ovarian endometriomas indicating severe disease (Table 4). 10 cases had bilateral tubal block. Cystectomy was the major procedure done (Table 5).

Surgically treated cases were given leuprolide injection, $3.75 \mathrm{mg}$, intramuscularly, one dose immediately following laparoscopic surgery, before going for induction of ovulation, intrauterine insemination (IUI) or artificial reproduction technology (ART) by in-vitro fertilisation (IVF) in the follow up. 
Table 4: Laparoscopic findings in women with endometriosis (50 cases).

\begin{tabular}{|lll|}
\hline $\begin{array}{l}\text { Characteristic } \\
\text { findings }\end{array}$ & $\begin{array}{l}\text { No. of } \\
\text { patients }\end{array}$ & Percentage \\
\hline $\begin{array}{l}\text { Site of endometriosis } \\
\text { Ovary }\end{array}$ & 16 & $32 \%$ \\
\hline Unilateral & 7 & $14 \%$ \\
\hline Bilateral & 9 & $18 \%$ \\
\hline POD & 5 & $10 \%$ \\
\hline $\begin{array}{l}\text { Posterior surface of } \\
\text { uterus }\end{array}$ & 3 & $6 \%$ \\
\hline Uterosacral ligaments & 2 & $4 \%$ \\
\hline \begin{tabular}{lll|} 
Adhesions(thick dense) \\
Present
\end{tabular} & 16 & $32 \%$ \\
\hline $\begin{array}{l}\text { Absent } \\
\text { Chromopertubation ( 33 cases of infertility) due } \\
\text { to endometriosis }\end{array}$ & 34 \\
\hline Unilateral patent tube & 3 & $9.09 \%$ \\
\hline Bilateral patent tubes & 20 & $66.6 \%$ \\
\hline Bilateral tubal block & 10 & $30.30 \%$ \\
\hline
\end{tabular}

Table 5: The methods of laparoscopic procedures done.

\begin{tabular}{|lll|}
\hline Surgical procedure & $\begin{array}{l}\text { Number } \\
\text { of cases }\end{array}$ & Percentage \\
\hline $\begin{array}{l}\text { Cystectomy } \\
\text { with/without } \\
\text { adhesiolysis }\end{array}$ & 12 & $24 \%$ \\
\hline $\begin{array}{l}\text { Chocolate cyst drainage } \\
\text { with fulguration }\end{array}$ & 04 & $08 \%$ \\
\hline $\begin{array}{l}\text { Adhesiolysis and } \\
\text { remodelling of anatomy }\end{array}$ & 09 & $18 \%$ \\
\hline $\begin{array}{l}\text { Bipolar cauterisation, } \\
\text { scissor excision of deep } \\
\text { lesions with } \\
\text { cauterisation }\end{array}$ & 25 & $50 \%$ \\
\hline
\end{tabular}

We had 25 cases in stage 3 and 4 out of which 5 patients conceived after treatment (Table 6).
Table 6: Table showing the success rate of pregnancy after laparoscopic surgery.

\begin{tabular}{|c|c|c|c|}
\hline $\begin{array}{l}\text { R-AFS } \\
\text { stage }\end{array}$ & $\begin{array}{l}\text { No. of } \\
\text { patient }\end{array}$ & Pregnant & $\begin{array}{l}\text { Percentage } \\
(\%)\end{array}$ \\
\hline Stage 1 & 04 & 04 & 100 \\
\hline Stage 2 & 04 & 03 & 75 \\
\hline Stage 3 & 15 & 04 & 26.66 \\
\hline Stage 4 & 10 & 01 & 10 \\
\hline total & 33 & 12 & 36.36 \\
\hline
\end{tabular}

The reproductive outcome shows some association with the R-AFS score in our study (Table 7).

Table 7: Fertility rate as per R-AFS scoring.

\begin{tabular}{|llll|}
\hline $\begin{array}{l}\text { R-A FS } \\
\text { stages }\end{array}$ & $\begin{array}{l}\text { Stage 1to2 } \\
\text { (minimal } \\
\text { to mild) } \\
{[n=25]}\end{array}$ & $\begin{array}{l}\text { Stage 3 } \\
\text { (moderate) } \\
{[n=15]}\end{array}$ & $\begin{array}{l}\text { Stage 4 } \\
\text { (severe) } \\
{[n=10]}\end{array}$ \\
\hline $\begin{array}{l}\text { No of } \\
\text { pregnancies } \\
(\%)\end{array}$ & $07(28 \%)$ & $04(26.66 \%)$ & $01(10 \%)$ \\
\hline $\begin{array}{l}\text { No of term } \\
\text { pregnancy } \\
(\%)\end{array}$ & 06 & $04(80 \%)$ & $01(100 \%)$ \\
\hline
\end{tabular}

In fertile patients (17 patients) with endometriosis, Medroxyprogesterone acetate (MPA) injection, 150mg intramuscularly was given at 3 monthly interval for 3 doses and thereafter followed up for pain relief and suppression of the disease process. In these cases more than $80 \%$ of women got good relief from symptoms of pelvic pain and dysmenorrhoea. Four patients underwent TAH with BSO.

Out of the 33 cases of infertility due to endometriosis, 12 $(36.36 \%)$ cases have conceived. Seven patients conceived naturally with clomiphene induction, in this one patient had spontaneous abortion. Two patients conceived by clomiphene and gonadotropin induction with IUI. Another three conceived by gonadotropin induction and ART by IVF in the nearby ART centre (one triplet and two twins).

Table 8: Comparison of pregnancy rates in various studies.

\begin{tabular}{|c|c|c|c|c|}
\hline Author & $\begin{array}{l}\text { No of infertile cases } \\
\text { due to endometriosis }\end{array}$ & $\begin{array}{l}\text { Stages of } \\
\text { endometriosis as per } \\
\text { R-AFS classification }\end{array}$ & $\begin{array}{l}\text { Pregnancy rate } \\
(\%)\end{array}$ & $\begin{array}{l}\text { Follow up } \\
\text { period }\end{array}$ \\
\hline & & (operated) & & \\
\hline Berrata al $(1998)^{24}$ & 64 & 3 and 4 & $66.7 \%$ & 2 years \\
\hline Jones and Sutton $(2002)^{31}$ & 39 & 2 and 3 & $39.5 \%(15)$ & 1year \\
\hline Elsheik et al $(2003)^{32}$ & 151 & 1 to 4 & $53 \%(80)$ & 2 years \\
\hline Godinjak et al $(2005)^{23}$ & 45 & 3 and 4 & $35 \%(15)$ & 1 year \\
\hline Fuchs et al (2007) ${ }^{28}$ & 34 & 1 to 4 & $65 \%(22)$ & 8.5 months \\
\hline Teksin Cirpan $(2013)^{33}$ & 52 & 1 to 4 & $44 \%(23)$ & 1 year \\
\hline Hye Jun Lee et al $(2013)^{34}$ & 43 & 1 to 4 & $41.9 \%(18)$ & 1 year \\
\hline Our study & 33 & 1 to 4 & $37 \%(12)$ & 2 years \\
\hline
\end{tabular}




\section{DISCUSSION}

Endometriosis remains a diagnostic as well as a therapeutic dilemma. It is considered as an enigma; hence it still intrigues researchers to addressing the cause and the management of the disease in every possible way. Endometriosis has a profound impact on quality of life, and developing a therapy that also improves fertility remains a challenge for gynaecologists.

The exact mechanism by which it causes infertility is still unclear. The projected sequences of the causes of infertility in cases of endometriosis are by an altered peritoneal fluid composition as a result of hormonal, genetic and environmental factors. ${ }^{6,7}$ One of the accepted theories is increased levels of prostaglandins, proteases, and cytokines and vascular endothelial growth factor (VEGF) in the peritoneal fluid. ${ }^{8}$ These alterations adversely affect the mechanism of ovum pick up, sperm motility, embryo quality and poor tubal function. These altered peritoneal fluid composition and adhesions cause severe tubal dysfunction, ${ }^{9}$ the actual prevalence is difficult to quantify because of its very wide range in various studies across the world. ${ }^{10-12}$ In one of the studies, it has been shown that approximately $47 \%$ of women with infertility have endometriosis. ${ }^{13}$ In a study done by Tsuzi et al, the prevalence was $63 \%$. In our study it is $73.33 \%$. The diagnostic utility of USG in endometriosis is limited, but it can give corroborative evidences when there are ovarian endometriomas. ${ }^{15}$

Medical management accepts the basic principle of reducing inflammation, suppressing ovarian cycles and inhibiting the effect of oestrogen but its role in treatment of infertility is limited. Medical management can be used prior to surgery to decrease the size of endometriotic lesions and the extent of the operation. Conservative surgical procedures like adhesiolysis and removal of endometriotic cysts with post-operative medical therapy with OCP for more than a year can give longer duration of pain relief and delay the anatomical recurrence rates. ${ }^{16-}$ 19

The studies in the Table 8 include observational studies, randomized controlled studies and non-randomized studies.

The pregnancy rate in our study was $36.36 \%$. The fertility outcome was better with stage 1 and stage 2 disease $(87.5 \%)$. The success rate in moderate to severe disease was $20 \%$. It was better in patients who underwent cystectomy in severe disease. After surgical treatment, the pregnancy rate and live birth rate did improve.

The recent advances in operative laparoscopy have changed the view in the management of endometriosis with infertility. The laparoscopic treatment involves the identifying and removal of lesions by cauterization, fulguration or laser evaporation for minimal to mild disease, adhesiolysis, excision of deep lesions, cystectomy, drainage and coagulation for endometriomas of ovary (moderate to severe disease). A randomized controlled trial (RCT) was done by the Canadian collaborative study on endometriosis reveal a definite improvement in fertility rate. Based on a systematic review and meta-analysis, the ESHRE guideline has proposed that ablation of endometriotic lesions with adhesiolysis in minimal to mild endometriosis improves fertility. A more recent meta-analysis revealed that the pregnancy rate increases after laparoscopic ablation in women with stage 1 and 2 endometriosis. ${ }^{21,22}$ Laparoscopic cystectomy for ovarian endometrioma (size more than 3-4cm: stage 3 and 4) results in improvements in pregnancy rates as compared with cyst drainage and coagulation. $^{23,24}$ In our study too we found a better outcome with cystectomy. The evidences from observational studies suggest that women who have stage 3 and 4 endometriosis without any other identifiable infertility factors may benefit from surgical treatment. ${ }^{25-26}$ A study by Charles Chaperon et al used surgical modality of treatment for endometriosis involving the uterosacral ligaments and obliteration of cul-de-sac. The overall intrauterine pregnancy rate, including births and abortions, was $50 \%$ (15 patients). 11 had spontaneous intra uterine pregnancy remaining 3 had induction of ovulation and one pregnancy occurred after IVF. 12 gave birth normally at term; one had an ectopic and remaining two had miscarriage. ${ }^{27}$ Fuchs $\mathrm{F}$ et al studied 64 patients with infertility in all stages by operative laparoscopy. 20 patients dropped out of study, 65\% (22) patients became pregnant within 8.5 months. $89 \%$ with stage 1 and 2 and $56 \%$ with stage 3 and 4 got pregnant within one month post-surgery. They recommend complete surgical treatment for such patients to increase their chance of conceiving spontaneously or by ART. ${ }^{28}$ In a study by Sahu L et al, the fertility rate was $46 \% .^{29}$ In our study the fertility rate is $(36.36 \%)$ comparatively lesser than other studies. The probable reason could be the higher prevalence of moderate to severe disease in infertile patients $(75.75 \%)$ and many patients with severe disease were unwilling to undergo ART due to financial constraints. It is generally believed the prevalence of endometriosis is less common in India, but in our study in the Wayanad district of Kerala it was $25 \%$ of all the reproductive women studied. The most common site was in the pelvis with obliteration of cul-de-sac and ovarian endometriomas (Figure 1 and 2). The diagnosis can be well established in all cases by laparoscopy and HPE confirmation. $^{30}$

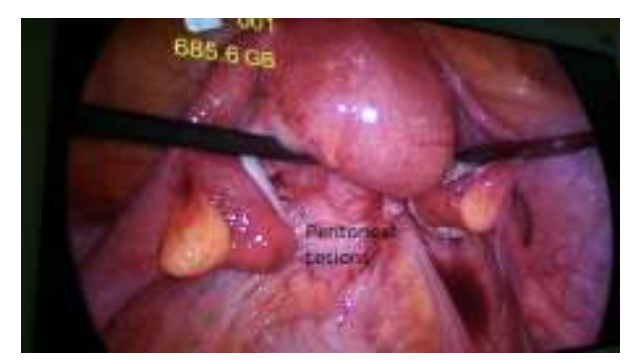

Figure 1: Showing powder burn red lesions (stage I). 


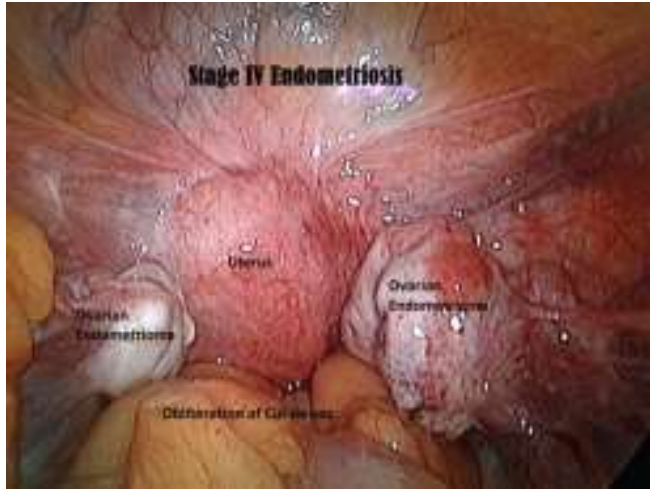

Figure 2: Showing ovarian endometrioma, obliteration of cul-de sac with peritoneal adhesions (stage IV).

\section{CONCLUSIONS}

Patients with symptoms of dysmenorrhoea, dyspareunia, pelvic pain, infertility and clinical signs of cul-de-sac tenderness with nodular surface, restricted mobility of uterus or fixed retroverted uterus with adnexal mass along with USG findings should raise the suspicion of endometriosis in infertility patients. In infertile patients with stage III/IV endometriosis, surgical management can be recommended for better results in fertility rates. Patients with stage 1 and 2 disease also benefit after operative surgery. The diagnostic and therapeutic dilemma of endometriosis in infertility patients can be solved by laparoscopy. Laparoscopy remains the gold standard for diagnosing the disease; staging and surgically managing such cases.

Funding: No funding sources

Conflict of interest: None declared

Ethical approval: The study was approved by the Institutional Ethics Committee

\section{REFERENCES}

1. Eskenazi B, Warner ML. Epidemiology of endometriosis. Obstet Gynecol Clin North Am. 1997;24:235-58.

2. Donnez J, Wyns C, Nisolle M. Does ovarian surgery for endometriomas impair the ovarian response to gonadotropin? Fertil Steril. 2001;76:662-5.

3. Burney RO, Giudice L. Pathogenesis and pathophysiology of endometriosis. Fertil Steril. 2012;98:511-9.

4. Carneiro MM, Filogônio I DDS, Costa LMP, De Ávila I, Ferreira MC. Accuracy of clinical signs and symptoms in the diagnosis of endometriosis. J Endometr. 2010;2:63-70.

5. Alkatout I, Mettler L, Beteta C, Hedderich J, Jonat $\mathrm{W}$, Schollmeyer T. Combined surgical and hormone therapy for endometriosis is the most effective treatment: prospective, randomized, controlled trial. J Minimal Invas Gynecol. 2013;20(4):473-81.
6. Gilabert-Estelles J, Ramon LA, España F, Gilabert J, Castello R, Estelles A. Expression of fibrinolytic components in endometriosis. Pathophysiol Haemost Thrombs. 2006;35:136-40.

7. Szczepańska M, Koźlik J, Skrzypczak J, Mikołajczyk M. Oxidative stress may be a piece in the endometriosis puzzle. Fertil Steril. 2003;79:128893.

8. Bedaiwy MA, Falcone T, Sharma RK, Goldberg JM, Attaran M, Nelson DR et al. Prediction of endometriosis with serum and peritoneal fluid markers: a prospective controlled trial. Hum Reprod. 2002;17:426-31.

9. Lebovic DI, Mueller MD, Taylor RN. Immunobiology of endometriosis. Fertil Steril. 2001;75:1-10.

10. Missmer SA, Hankinson SE, Spiegelman D, Barbieri RL, Marshall LM, Hunter DJ. Incidence of laparoscopically confirmed endometriosis by demographic, anthropometric, and lifestyle factors. Am J Epidemiol. 2004;160:784-96.

11. Stilley JA, Birt JA, Sharpe-timms KL. Cellular and molecular basis for endometriosis associated infertility. Cell tissue Res. 2012;349:849-62.

12. Pfeifer S, Fritz M, Goldberg J, McClure R, Lobo R, Thomas $\mathrm{M}$ et al. Practice committee of american society for reproductive medicine. Endometriosis and infertility: a committee opinion. Fertil Steril. 2012;98:591-98.

13. Meuleman C, Vandenabeele B, Fieuws S, Spiessens C, Timmerman D, D'Hooghe T. High prevalence of endometriosis in infertile women with normal ovulation and normospermic partners. Fertil Steril. 2009;92:68-74.

14. Ami TK, Miyazaki A, Hujinami N, Hoshiai $H$. Benefit of diagnostic laparoscopy for patients with unexplained infertility and normal hysterosalping graphy findings. Tohoku. J Exp Med. 2009;219:3942.

15. Patel MD, Feldstein VA, Chen DC, Lipson SD, Filly RA. Endometriomas; diagnostic performance of US. Radiol. 1999;210(3):739-45.

16. Giudice LC. "Endometriosis". The New England J Med. 2010;362:2389-98.

17. Kennedy S, Bergqvist A, Chapron C, D'Hooghe T, Dunselman G, Greb R et al. "ESHRE guideline for the diagnosis and treatment of endometriosis. Human Reprod. 2005;20:2698-704.

18. Yap C, Furness S, Farquhar C. Pre and postoperative medical therapy for endometriosis surgery. Cochrane Database Syst Rev. 2004;3. Article ID CD003678.

19. Seracchioli R, Mabrouk M, Manuzzi L, Vicenzi C, Frascà C, Elmakky A et al. Post-operative use of oral contraceptive pills for prevention of anatomical relapse or symptom-recurrence after conservative surgery for endometriosis. Human Reprod. 2009;24:2729-35.

20. Marcoux S, Maheux R, Berube S. Laparoscopic surgery in infertile women with minimal or mild 
endometriosis. Canadian Collaborative Group on Endometriosis. N Engl J Med. 1997;337(4):217-22.

21. Jacobson TZ, Duffy JM, Barlow D, Farquhar C, Koninckx PR, Olive D. Laparoscopic surgery for subfertility associated with endometriosis. Cochrane Database Syst Rev. 2010;(1):CD001398.

22. Duffy JM, Arambage K, Correa FJ, Olive D, Farquhar C, Garry R et al. Laparoscopic surgery for endometriosis. Cochrane Database Syst Rev. 2014;4:CD011031.

23. Godinjak Z, Idrizbegovic E, Begic K, Sengil N. Pregnancy after laparoscopic treatment of ovarian endometriotic cysts. Med Arh. 2005;59:351-3.

24. Beratta P, Francho M, Ghezzi F, Busacca M, Zupi E, Bolis P. Randomised clinical trial of two laparoscopic treatment of endometriosis :cystectomy drainage and coagulation. Fertil Steril. 1998;70:1176-80.

25. Crosgnani PG,Vercellini $P$ et al. Laparoscopic vs laparotomy in conservative surgical treatment of severe endometriosis. Fertil Steril. 1996;66:706-11.

26. Schenken PS. Modern concepts of endometriosis. Classification and its consequences for therapy. J Reprod Med. 1998;43:269-75.

27. Chapron C, Fritel X, Dubuisson JB. Fertility after laparoscopic management of deep endometriosis infiltrating the uterosacral ligaments. Hum Reprod. 1999; 14:329-32.
28. Fuchs F, Ravnal P, Salama S et al. Reproductive outcome after laparoscopic treatment in an infertile population. J Gynaecol Obstet Biol Reprod (Paris). 2007;36:162-72.

29. Sahu L, Tempe A. Laparoscopic management of endometriosis in infertile women and outcome. Int $\mathbf{J}$ Reprod Contracept Obstet Gynecol. 2013;2:177-81.

30. LH Albert, K Izabella, S Pamela. Invasive and noninvasive methods for diagnosis of endometriosis. Cliobstet gynecol. 2010;53:413-19.

31. Jones KD, Sutton CJ. Pregnancy rates following ablative laparoscopic surgery for endometriomas. Hum Reprod. 2002; 17:782-85.

32. Elsheikh A, Milingos S, Loutradis D, Kallipolitis G, Michalas S. Endometriosis and reproductive disorders. Ann N Y Acad Sci. 2003;997:247-54.

33. Teksin C, Levent A, Mehmet S Y, Mustafa C T, Mert K. Reproductive Outcome After Surgical Treatment of Endometriosis- Retrospective analytical study. Ginekol Pol. 2013;84:1041-4.

34. Lee HJ, Lee JE, Ku SY, Kim SH, Kim JG, Moon SY. Natural conception rate following laparoscopic surgery in infertile women with endometriosis. Clin Exp Reprod Med. 2013;40:29-32.

Cite this article as: Valson $\mathrm{H}$, Kulkarni C, Teli B, Nazer T. Study of endometriosis in women of reproductive age, laparoscopic management and its outcome. Int J Reprod Contracept Obstet Gynecol 2016;5:514-9. 